It is the wish of the Regiment that you forward them to the State Historical Society, there to be retained subject to the order of the Commanding Officer of the Regiment.

Respectfully, your obedient servant,

W. M. G. TORRENCE,

Colonel Commanding.

Copy : N. B. BAKER, Adj't Gen'l of Iowa.

\title{
OFFICERS OF THE STATE HISTORICAL SOCIETY FOR 1864.
}

President-His Excellency, Sam'l J. Kirkwood, of Iowa City.

Vice Presidents-Hon. G. W. McCleary, Pres. O. M. Spencer, D. D., Hon. F. H. Lee-all of Iowa City ; Willard Barrows, Esq., of Davenport; Capt. H. B. Horne, of Bloomfield; and Col. Wm. M. Stone, Governor elect, of Des Moines.

Corresponding Secretary and Librarian-Prof. T. S. Parvin, of Iowa City.

Recording Secretary-James W. Morrison, of Iowa City. Treasurer-J. P. Wood, of Iowa City.

Board of Curators-Pres. O. M. Spencer, D. D., Rev. M. S. Osmond, Hon. F. H. Lee, G. H. Jerome, Esq., J. P. Wood, Esq., Hon. G. W. McCleary, Prof. Jas. T. Roberts, D. D., William Crum, Esq., I. N. Jerome, Esq., Prof. N. R. Leonard, Rev. S. S. Howe, J. R. Hartsock, Esq., Rev. F. M. Gray-all of towa City; Rev. W. Barris, of Burlington; Hon. Wm. H. Tuthill, of Tipton; Col. H. A. Wiltse, of Dubuque; Hon. J. B. Grinnell, of Grinnell; Hon. E. Price, of Guttenburg.

Comartiee of Publication.-The Committee consists of Oliver M. Spencer, D. D., President of the State University, Chairman, N. R. Leonard, Professor in the State University, and Rev. Samuel Storrs Howe, Acting Editor of the Annals of Iowa.

All communications and subscriptions may be sent to the Editcr of the Annals, Iowa City, Iowa. 
Copyright of Annals of Iowa is the property of State of Iowa, by \& through the State Historical Society of Iowa and its content may not be copied or emailed to multiple sites or posted to a listserv without the copyright holder's express written permission. However, users may print, download, or email articles for individual use. 